ROCZNIKI FILOZOFICZNE

Volume LXIX, issue 3-2021

DOI: https://doi.org/10.18290/rf21693-2

PAUL K. MOSER

\title{
EXPERIENTIAL DISSONANCE AND DIVINE HIDDENNESS
}

\section{WHICH GOD?}

Talk of God tends to be too easy for humans. Historically, we humans have used the term "God" for a wide range of beings, covering such differing figures as Apollo, Baal, Brahma, Krishna, Marduk, Osiris, Vishnu, Yahweh, and Zeus. The list is much longer than this sample, of course, but the point is clear: People have meant very different things with the term "God," with incompatibility at various points. Human talk of God yields an abundance of supposed gods, but they cannot all be God if consistency of character matters. For instance, some gods call for child sacrifice and genocide by humans, whereas other gods deplore those evils. This kind of conflict prompts a simple question: What would it take to be God, rather than to be just an alleged god? The answer is, as expected, complicated.

According to an important strand within the monotheism of Judaism, Christianity, and Islam, the term (or at least the notion of) "God" is a perfectionist title requiring worthiness of worship and hence perfect moral goodness of any titleholder. Being or doing evil thus excludes an agent from being God. The perfectionist title sets the standard as high as possible for being God, and it is a helpful place to start. We can lower the standard later if problems emerge for the maximally exalted title. For now, we start at the top, inquiring about a morally perfect God.

Worthiness of worship entails worthiness of full commitment from humans, even if they have difficulty with full commitment to God. The required full

Paul K. Moser, Professor of Philosophy, Loyola University Chicago; correspondence address: 1032 West Sheridan Road, Chicago, IL 60660-1537, USA; e-mail: pmoser@luc.edu; ORCID: https://orcid.org/0000-0002-5036-4588. 
commitment demands full love, trust, and obedience toward God, come what may. God's moral character thus would result in God's being demanding toward humans in this regard. Being perfectly good entails being perfectly loving toward humans, and being perfectly loving entails being perfectly caring toward humans regarding what is best for them, all things considered. God therefore would seek to be redemptive toward wayward humans, by attracting and leading them to (ever-deepening) reconciliation with God. Such reconciliation would call for God's self-presenting divine goodness to humans and for humans' responding by agreeably cooperating with God above all else. We need to consider how this kind of interpersonal reconciliation would figure in human experience of God and in divine hiddenness.

\section{DIVINE GOODNESS AND DISSONANCE}

The God of monotheism would be uniquely worthy of worship. So, God's self-presentation of perfect moral goodness would be unique and thus would differ from the moral goodness typical of humans. It would indicate God's reality and presence, thus differing from lesser manifestations of goodness in human experience, such as the goodness arising from a human. The divine selfmanifestation of perfect goodness would not come to humans for their entertainment or amusement. Instead, it would bring God's perfectly redemptive aim toward humans in need: the aim to attract them to divine-human reconciliation as agreeable cooperation with God. So, the self-manifestation would arise from an unfulfilled divine goal for humans, even if they are initially unclear about the goal and even if they oppose or neglect the goal.

The felt conflict between God's self-manifested moral character or will and a typical human moral character or will would include an internal dissonance or discord in human experience. The Oxford English Dictionary offers the following definition of "dissonance": "want of concord or harmony (between things); disagreement, incongruity." It also offers this as a definition: "an inharmonious sound." Using auditory language, we might think of God's perfect character as yielding "an inharmonious sound" in the experience of a wayward human, the disharmony stemming from its conflict with "the sound" of a morally inferior human character.

A key part of God's perfect moral character would be the perfect divine will regarding humans, that is, God's intentional resolve and plan toward humans. The divine will, in its moral perfection, would be incongruous with 
a wayward human will, and this would yield moral dissonance in human experience. We would have a conflict between two wills, one perfect and the other imperfect. From a moral point of view, God's will would have priority, with no serious moral challenge from an inferior human will.

Suppose, for instance, that I intend to defraud my elderly next-door neighbor. He has come to me for investing advice, and I have agreed to invest a large sum of his money in an account under my name. My plan is to skim from his investment money for my own gain, even though I have told him that my service is free. In the quiet of the night, however, I am struck with a guilty conscience regarding my plan. My conscience delivers, without coercion, volitional pressure against my intention to defraud. It gives me a sense of an alternative attitude to my neighbor that attracts me and creates dissonance with my initial intention. It presents a moral character and a will to me that conflict with my own character and will regarding my neighbor. I am left with morally relevant dissonance in my experience. This experiential dissonance is part of my awareness, in attracting my attention, whatever interpretation I bring to it.

I have a decision to make regarding my conflicted experience in conscience. I could (a) ignore the dissonance and divert my attention away from it, (b) resist or oppose the volitional pressure to refrain from defrauding my neighbor, or (c) cooperate with the challenge to refrain from the defrauding. Options (a) and (b) would amount to my failing to cooperate with the goodness manifested in my conscience. They are not the same decision, but from the standpoint of my favoring the presented goodness in my experience, they entail my being uncooperative. They could amount to my deciding against God and the divine goodness presented in my experience.

The dissonance in my experience would not be just cognitive, as a matter of conflicting pieces of knowledge, or even just doxastic, as a matter of conflicting beliefs. It would go deeper, to my experiences that underlie my beliefs or knowledge. So, talk of either doxastic dissonance or cognitive dissonance would not capture the reality of my situation. An adequate phenomenology of my experience must attend to the features of my experience, regardless of what I know or believe about my experience. If God's will shows up in my experience, I will do well to consider my experience of it, even if my relevant knowledge or belief lags behind.

In my guilty conscience at night, I confront volitional pressure presented as part of my moral experience. It disturbs my sleep, but it does not force my decision in response. It challenges me, in the experienced dissonance, not to defraud my neighbor, but I am left to respond, freely. On reflection, I consider 
the volitional pressure in conscience to be part of God's will toward me. I have been presented with moral goodness that manifests God's character, and it goes against my devious will to defraud my neighbor. God's self-manifested will challenges me to care for my neighbor rather than to defraud him. It thus aims to frustrate my morally inferior will and character, for the sake of realizing God's better will. Morally, it calls me up short, seeking to attract me to cooperate with God's good will instead of my inferior will.

The presentation of a good will in my moral experience in conscience has a distinctive feature. It nudges me toward cooperative conviction in a way best described as seeking to lead me to cooperate with divine goodness. Its uncoercive nudging comes to me as goal-directed and thus as intentional. So, it does not simply present content to be described by me. Instead, it presents a morally relevant volition that conflicts with my intention to defraud, and it aims to attract me to let go of my decision to defraud. Its intentional feature of goaldirectedness indicates a person, an intentional agent, at work in the dissonance of my moral experience.

Only a person would aim to lead me; a mere object or idea would not be intentional in that way. In addition, the person in question differs from me, having a better will than mine, and that person conflicts with my will. Of course, I can contradict myself, but I am not doing so here; I am behind only the inferior will, at least initially. The better will is not mine; it only meets my will with dissonance, seeking to frustrate my will to defraud, for the sake of my moral improvement.

My basic, foundational evidence for God's reality and presence comes from the divine self-manifestation of God's good character and will in my experience. That evidence is experiential; it is not a belief or an argument. It is something qualitatively featured, in a morally relevant way, that I meet in my experience, and it goes against some of my familiar ways. When this evidence is undefeated, relative to my total evidence, it can confer epistemic justification on my belief that God exists.

Going beyond my experience itself, I can reason and formulate arguments about my experiential evidence, and I can present my belief that God exists as central to a best available explanation of my overall experience. That belief is my best available answer to this explanation-seeking question: Why am I having my present experience of moral dissonance rather than some other experience or no experience at all? A role for God's moral intervention figures in the best 
available explanation, given my overall evidence. Even so, my basic evidence of God's reality is experiential, and not a belief or an argument. ${ }^{1}$

With perfect redemptive caring, God would seek, at God's preferred time, to frustrate and subject to futility anything contrary to the intended redemption, including wayward human aims. Paul thus remarks: "The creation was subjected to futility, not of its own will but by the will of the one who subjected it, in hope that the creation itself will be set free from its bondage to decay and will obtain the freedom of the glory of the children of God" (Rom 8:20-21). The divine subjection of creation to futility would include the subjecting of an opposing human will to frustration and futility when God deems suitable. God would use dissonance in moral experience, including in conscience, to challenge human wills in conflict with God's will. The challenge would be toward their conformity with God's better, perfect will. So, the kind of moral dissonance in experience we have noted would have a divine purpose: the redemption of wayward humans in reconciliation with God. We need to clarify how such dissonance figures in this purpose.

\section{INTEGRATION OR DISINTEGRATION}

The dissonance in moral experience yields a conflict within a person that threatens this person's moral integration or unity. It results in moral disintegration, at least for a time. A natural response by the prophet Isaiah to the dissonance from God is found in the book of Isaiah: "Woe is me! I am lost, for I am a man of unclean lips, and I live among a people of unclean lips; yet my eyes have seen the King, the Lord of hosts!" (Isa. 6:5, NRSV here and in following biblical translations). A similar response came from the apostle Peter: "Simon Peter ... fell down at Jesus's knees, saying, 'Go away from me, Lord, for I am a sinful man!'" (Luke 5:8). The pain of the moral dissonance thus can prompt a desire for escape from the challenge.

An escape can come either from ignoring or rejecting the challenge from God or from agreeably cooperating with it. As long as the challenge persists, I will suffer a kind of moral disintegration. I will have an unresolved moral conflict in my moral experience and conscience that hinders the unity or integration of my moral life. I then will face moral division within. It will

\footnotetext{
${ }^{1}$ For elaboration of this position, see Paul K. MOSER, Understanding Religious Experience (Cambridge: CUP, 2020), chap. 7-8. See also Moser, The God Relationship (Cambridge: CUP, 2017), chap. 5 .
} 
threaten my acting as a consistent moral agent, giving a nudge in opposing directions.

I have two main options, available for my free decision: on the one hand, I can ignore or reject God's better will and, on the other hand, I can cooperate with it. Either option would remove the dissonance, at least from my awareness. If I ignore or reject God's better will for the sake of my inferior will, I choose the moral low road. I then persist, for instance, in my intention to defraud my neighbor, and my moral life will tend to go from bad to worse. This will be a moral life at odds with God, but I will have silenced my conscience, at least for a time, by ignoring or rejecting God's better will. This is an ongoing risk for moral agents inclined to choose their own ways over God's will. We can suppress the divine attraction of conscience, even when God is at work in conscience.

We have the option to refuse cooperating with God's moral will and thus to refuse entering God's moral world as willing participants. Likewise, on the doorstep of a striking cathedral, we can choose not to enter but to view its stained-glass windows at most only from outside. We then see at most only dark shades on the windows, from their protective coverings, and not the bright colors seen from inside the cathedral. We then miss out on the attractive power of the beautiful windows, because we have not put ourselves in a position to behold their attractive power in its fruition.

Choosing to enter the cathedral can make a big difference. It can bring us acquaintance with the enlivening power of the windows' colorful beauty. Entering the cathedral is analogous to entering God's moral world by cooperating with God's will. Using moral dissonance, God invites people to enter the cathedral with appreciation of the beauty within and its depth. It is then their moral move, as free agents, to accept the invitation or not to accept it. Coercion of humans is not a live option here. People can stay outside, in relative color deprivation. In doing so, they can seek to integrate their moral lives without divine involvement. God, however, may have other plans for their lives.

Entering God's moral world, with my due cooperation, brings integration to my moral life around divine goodness. It puts God's will first in my life, and it takes me beyond the dissonance that threatened to leave me with moral disintegration. My cooperation, however, need not be perfect; it is enough that it be on balance for directing my life toward God's will. The ideal is perfect cooperation, but this ideal may be realized only in the fullness of time.

For now, my overarching decision is for God's will, accompanied by a struggle to follow through in particular cases. My overarching decision, in addition, leaves me struggling against my initial intention to defraud my 
neighbor. It contributes, as it happens, to my finally saying no to defrauding my neighbor. God's will is thus realized, in my cooperation. I have entered God's moral world as a willing participant, and it differs from my self-made moral world. It has an interpersonal feature that leaves me with profoundly good moral challenges, beyond the challenges from other humans.

The apostle Paul thought of a suitable human response to God in terms of a person's being led by God, upon, and in keeping with, divine intervention in experience. He thus commented that: "It is God who is at work in you, enabling you both to will and to work for his good pleasure" (Phil. 2:13). This perspective acknowledges the importance of God's enabling, but not coercing, people to will in a certain way. The divine enabling involves an experience of God's moral character and will of righteous love as evidence that sets a moral standard for a person: "Hope [in God] does not disappoint us, because God's love has been poured into our hearts through the Holy Spirit that has been given to us" (Rom. 5:5). This love is a divine self-manifestation of God's moral character and love, and Paul thought of it as not only experienced but also motivating for a person. $\mathrm{He}$ thus remarks: "The love of Christ urges us on," on the assumption that this is God's love from Christ (2 Cor. 5:14). This kind of divine motivating guidance toward cooperative people figures in his understanding of being a child of God: "All who are led by the Spirit of God are children of God" (Rom. 8:14).

Being led by God is being attracted by God's perfect goodness to cooperate with God's will self-manifested in experience. This kind of being led guides a person, without coercion, to conform to God's moral character in reconciliation with God. In being thus led, a human moral character is integrated with divine goodness, thereby bringing unity to one's moral experience and conscience. It also receives experiential evidence of God's presence in a human life, while undergoing moral renewal in conjunction with human cooperation with God. The evidential and the moral work together in a transformative manner as humans cooperate with God.

Owing to redemptive cooperation, a significant transformation occurs in human moral character, and this bears on human evidence of God. Rufus Jones has remarked:

The monumental evidence of God is, I believe, the fact of spiritual personality through which divine traits of character are revealed. Stars and mountains and ordered processes of nature reveal law and mathematics and beauty, but they reveal and can reveal no traits of character, no qualities of personality, no warmth and intimacy of heart and mind. If we are ever to be convinced that self-giving love is a reality of God's nature, we shall be convinced by seeing this love break through some human organ of [God's] Spirit. ${ }^{2}$

\footnotetext{
${ }^{2}$ Rufus Jones, Pathways to the Reality of God (New York: Macmillan, 1931), 217.
} 
Human personality transformation toward God's character or personality stems from divine leading as a human cooperates with the self-manifestation of God's will in human experience. Viewed from the inside, with one's cooperating with God's will, the transformation can give one firsthand experiential evidence of divine intervention and presence. Viewed from the outside, apart from one's participation with God, the evidence will tend to be ambiguous at best for a person, given one's lacking the firsthand experience of divine leading. So, we should not expect the relevant evidence to be universally compelling. Its interpersonal volitional nature accounts for that.

Divine character-transformation of a human goes beyond the following of moral rules to the interpersonal cooperation of a human with God as self-presented in moral experience. Morality thus takes on new depth and power in this interpersonal perspective, courtesy of God's empowering role. The newness will be apprehended by people inside, who join in cooperation with God. They will be like the people who see the bright colors of the stained-glass windows from inside the cathedral. They will have an evidential and moral perspective of divine work unknown to people who choose to remain outside. They will know the morally powerful leading of God firsthand, while those people outside will not.

The divine leading is not human self-leading, because the moral depth of the leading is not resident in typical humans. This becomes clear, and the plot thickens, once we acknowledge that the divine leading moves in a direction atypical for humans: love of enemies as willing what is good for them. Jesus was clear about this demanding direction God takes, in keeping with God's perfect moral character:

You have heard that it was said, "You shall love your neighbor and hate your enemy." But I say to you, Love your enemies and pray for those who persecute you, so that you may be children of your Father in heaven; for he makes his sun rise on the evil and on the good, and sends rain on the righteous and on the unrighteous. For if you love those who love you, what reward do you have? Do not even the tax collectors do the same? And if you greet only your brothers and sisters, what more are you doing than others? Do not even the Gentiles do the same? Be perfect, therefore, as your heavenly Father is perfect. (Matt. 5:43-48; cf. Luke 6:32-36) ${ }^{3}$

\footnotetext{
${ }^{3}$ On the historical background and integrity of this passage, see John MeIER, A Marginal Jew, vol. 4, Law and Love (New Haven, CT: Yale University Press, 2009), 499-27. See also Victor Paul Furnish, The Love Command in the New Testament (Nashville, TN: Abingdon Press, 1972), 62-69.
} 
According to Jesus, we must allow God's leading to guide us to love of our enemies if we are to be children of God. He anchored this demand in God's moral perfection, and he offered no exceptions to the scope of divine love's demand.

Jesus used the parable of the prodigal son to illustrate God's quest for divine-human reconciliation even with people opposed to God's perfectly loving ways (Luke 15:11-32). ${ }^{4} \mathrm{He}$ also manifested the love in question with his befriending and eating with social outcasts of questionable moral standing. In addition, he expected the same of his followers (Matt. 25:34-45). So, entering God's moral world, with due cooperation, may be integrating with divine goodness, but it is not easy or casual for typical humans. Given wayward human moral tendencies, we should not expect acquaintance or cooperation with a God of perfect goodness to be easy or casual. Instead, we should expect a struggle with dissonance for the sake of realizing divine goodness in our lives. We turn to some important implications of divine hiddenness regarding evidence of God.

\section{DIVINE HIDING AND SEEKING}

Talk of divine hiddenness is ambiguous between talk of God's hiding something about God, for whatever reasons, and talk of humans' doing something that, intentionally or unintentionally, hides or obscures evidence regarding God. An author of the book of Isaiah had the first option in mind: "Truly, you are a God who hides himself, O God of Israel, the Savior" (Isa. 45:15). Likewise for Jesus: "At that time Jesus said, 'I thank you, Father, Lord of heaven and earth, because you have hidden these things from the wise and the intelligent and have revealed them to infants; yes, Father, for such was your gracious will"' (Matt. 11:25-26; cf. Luke 10:21). ${ }^{5}$ God is doing the hiding here, actively, and one result is divine hiddenness regarding evidence of God

\footnotetext{
${ }^{4}$ For discussion of the role of divine love in the self-understanding and mission of Jesus, see Paul K. Moser, The Divine Goodness of Jesus (Cambridge: CUP, 2021), chap. 3.

${ }^{5}$ On the historical integrity of this verse, see W. D. DAvies and Dale C. Allison, Jr., A Critical and Exegetical Commentary on the Gospel According to Saint Matthew (Edinburgh: T\&T Clark, 1991), 2:275-76. See page 278 for their comment in favor of the historical authenticity of Matthew 11:25-26, with their conclusion that "the arguments could hardly be stronger." See also A. M. HunTER, "Crux Criticorum-Matt. 11:25-30-A Re-Appraisal," New Testament Studies 8 (1962), 241-49. On the parallel passage in Luke and its authenticity, see Joseph A. FITZMYER, The Gospel According to Luke (New York: Doubleday, 1985), 2:864-76.
} 
for some humans at some times. It does not follow, of course, that God hides from all humans at all times.

The second kind of divine hiddenness stems from human obstruction, intentional or unintentional, of God's intended self-manifestation. This alternative assumes that God is not coercive in divine self-manifestation but allows for human obstruction of it (and thereby of God) for themselves. Since God seeks agreeable cooperation from humans in their redemption as divine-human reconciliation, divine coercion of humans would defeat the purpose. So, God's gambit for redemption takes the risk of human neglect, opposition, and rejection toward God. The kind of righteous love God seeks fits with that gambit; it allows for human freedom to ignore or to reject that love.

God's occasional hiding, stemming from perfectly redemptive caring toward humans, would aim to bring humans to reconciliation with God at an opportune time. It would give relevant humans needed room to experience life without God's presence and perhaps to apprehend its difficulty and even longterm futility without God. In doing so, it would avoid a divine intervention that further alienates some humans from God. Some humans would resent God's interfering in their affairs, despite good divine intentions at work. Timing thus matters in divine self-manifestation, because humans are not always ready to cooperate with it or even to tolerate it. God, of course, would not want any person to choose final rejection of God, and would offer divine selfrevelation accordingly. This would include God's postponing self-revelation for a person until that person is more receptive.

Divine self-manifestation to wayward humans would typically aim at their cooperative redemption in reconciliation with God. The issue of why God is not more transparent in self-manifestation, including transparent to more people, should be set in this context. If I am not agreeable toward the cooperative redemption on offer, I easily could ignore, reject, or distort the relevant evidence for it. God then could take the initiative in self-hiding from me until a better, more opportune time for reconciliation. Alternatively, $I$ could secure the hiddenness of relevant divine evidence by ignoring or rejecting any initial self-manifestation from God, and God could allow my negative response. Part of God's allowing it would be God's refraining from self-manifestation to me for the time being.

We now can see how some people could find themselves without definite evidence of God's reality. God could honor their preference not to have such evidence. At least God could postpone giving such evidence to them owing to their not being willing to respond in a constructive way. Their not having the 
evidence of God they would neglect is, however, no basis for general agnosticism or atheism. Other people still could have definite undefeated evidence of God's reality, given their cooperation with the divine intervention in their moral experience.

People opposed to divine intervention could get an initial moral challenge from God, and thus initial tentative evidence, but their opposition, whether through indifference or rejection, could leave them with an absence of definite divine evidence. In that regard, God would allow for human resistance to divine self-manifestation and the definite evidence it can supply. This option would fit with God's seeking the agreeable reconciliation rather than the alienation of humans.

Philosophers have tended to neglect the redemptive aim of divine self-manifestation and the evidence it supplies to humans. They typically have thought of the evidence of God's reality as being suited to observers indifferent to cooperation with God's will. They thus have tended to stand outside of God's moral world with their assessment of the relevant evidence. In doing so, they have contributed to divine hiddenness, either by obscuring divine evidence themselves or by prompting God to hide relevant evidence until a more opportune redemptive time. In either case, they have excluded themselves from being in a reliable position to assess relevant evidence of divine self-manifestation. Their uncritical neglect of this prospect regarding their unreliability has made their epistemic position doubly inadequate, at the first and second levels. Much of the philosophical literature on divine hiddenness suffers on this front.

Remaining outside of God's moral world, through unwillingness to cooperate, will make one an unreliable observer of available evidence of God's reality. It amounts to pushing away the evidence, instead of receiving it for what it is intended to be: a reconciliatory source of cooperation with God's morally powerful will. Pushing it away, without cooperation, will leave one devoid of experiencing God's power to motivate and guide one toward God's perfect goodness, come what may.

Jesus told a story with an important but widely neglected lesson: "If they do not listen to Moses and the prophets, neither will they be convinced even if someone rises from the dead" (Luke 16:31). His point was that observing striking phenomena pertinent to God from outside of cooperation with God's self-presented will blocks a person from the cogent effectiveness of divine intervention. It leaves one without the experienced divine power that moves one, via intended cooperation with it, to be reasonably convinced of its reality. The result is a kind of divine hiddenness that counts against a general skepticism about divine evidence but not against God's reality. 


\section{PHILOSOPHY AND INVITATION}

Philosophers often fail to find an adequate evidential basis for commitment to a God worthy of worship. This typically results from their looking in the wrong places. The evidential basis is not in the nature of causation, the complexities of nature, a concept of God, or some elaborate argument. As long as philosophers neglect the divine challenge and invitation grounded in moral experience, they will miss the focal evidence and its call to enter God's moral world.

We see the role of a redemptive call in the following invitation attributed to Jesus: "I am standing at the door, knocking; if you hear my voice and open the door, I will come in to you and eat with you, and you with me" (Rev. 3:20). Note the role of being willing to hear and to open the door. This is the equivalent of entering God's moral world, with willingness to cooperate with God's perfect will manifested in human experience. Philosophers who neglect this live option for salient evidence of God do not give such evidence a fair hearing. They suffer from bias and miss out on the distinctive interpersonal and redemptive nature of such evidence.

Perhaps some inquirers prefer not to engage the kind of morally challenging evidence from a God worthy of worship. A god of deism would be more convenient, morally, and no god at all may be even more convenient. In any case, a God worthy of worship is socially unsettling, given human moral tendencies. Jesus thus said: "Do you think that I have come to bring peace to the earth? No, I tell you, but rather division!" (Luke 12:51; cf. Matt. 10:34-37). God's ultimate aim would be peace among people of good will, but without good human will, human clashes with God are inevitable.

God would not sacrifice genuine moral goodness for human agreement. Instead, God would allow divine goodness to prompt divisions among humans for the sake of their being attracted to cooperate with that goodness. In the divisions, they can, and perhaps even should, come to see the special value of divine goodness and the futility of alternatives to it. The evidence of God would come to humans in the midst of such divisions and create dissonance for them. Moral conflict and struggle would mark the context of that evidence. God would intend the dissonance to be redemptive.

We now face some concluding questions: Are we humans hiding from God and God's redemptive gambit? Is our manner of supposedly disengaged inquiry about God designed to protect our hiding from God? Do we choose, with our relatively casual manner of inquiry, to remain outside of God's moral world, while nonetheless appointing ourselves as evaluators of God's reality? 
Are we open to the prospect that God resides at a level of reality that is morally deeper than our level, and this bears directly on our inquiry about God? $\mathrm{Hu}-$ man inquirers about God should face such self-reflective question, for the sake of acquiring truth and avoiding error. In facing them, with due moral courage and candor, they may find that inquiry about God, if done right, goes deeper into reality than traditional philosophy would suggest.

\section{BIBLIOGRAPHY}

Davies, W. D., and Dale C. Allison, Jr. A Critical and Exegetical Commentary on the Gospel According to Saint Matthew. Vol. 2. Edinburgh: T\&T Clark, 1991.

FitZMYer, Joseph A. The Gospel According to Luke. New York: Doubleday, 1985.

Hunter, A. M. "Crux Criticorum-Matt. 11:25-30-A Re-Appraisal." New Testament Studies 8 (1962): 241-49.

Jones, Rufus. Pathways to the Reality of God. New York: Macmillan, 1931.

MeIER, John. A Marginal Jew. Vol. 4, Law and Love. New Haven, CT: Yale University Press, 2009.

Moser, Paul K. The Divine Goodness of Jesus. Cambridge: Cambridge University Press, 2021.

Moser, Paul K. The God Relationship. Cambridge: Cambridge University Press, 2017.

Moser, Paul K. Understanding Religious Experience. Cambridge: Cambridge University Press, 2020.

\section{EXPERIENTIAL DISSONANCE AND DIVINE HIDDENNESS}

\section{S u m m a ry}

Our expectations for human experience of God can obscure the reality and the presence of such experience for us. They can lead us to look in the wrong places for God's presence, and they can lead us not to look at all. This article counters the threat of misleading expectations regarding God, while acknowledging a role for diving hiding from humans on occasion. It contends that, given God's perfect moral character, we should expect typical human experience of God to have moral dissonance, that is, experiential conflict in morally relevant ways. We shall see the evidential or cognitive importance of how humans respond to such dissonance. Our failing to respond cooperatively with God can result either in our obscuring evidence of divine reality or in God's hiding divine selfmanifestation for redemptive purposes aimed at our benefit.

Keywords: Divine hiddenness; religious experience; experiential dissonance; divine manifestation. 


\section{DYSONANS DOŚWIADCZENIOWY I BOŻE UKRYCIE}

\section{Streszczenie}

Nasze oczekiwania dotyczące ludzkiego doświadczenia Boga mogą przesłonić nam rzeczywistą obecność takiego doświadczenia. Mogą nas skłonić do szukania obecności Boga w niewłaściwych miejscach i mogą sprawić, że w ogóle nie będziemy jej szukać. Artykuł przeciwstawia się groźbie mylących oczekiwań dotyczących Boga, jednocześnie uznając rolę okazyjnego Bożego ukrycia. Twierdzi się w nim, że biorąc pod uwagę doskonały charakter moralny Boga, powinniśmy oczekiwać, że typowe ludzkie doświadczenie Boga będzie zawierać dysonans moralny. Artykuł pokazuje dowodowe lub poznawcze znaczenie tego, jak ludzie reagują na taki dysonans. Nasza niezdolność do współdziałania z Bogiem może skutkować albo zaciemniającym dowodem boskiej rzeczywistości, albo ukrywaniem przez Boga jego samoobjawienia dla celów odkupieńczych skierowanych na naszą korzyść.

Słowa kluczowe: Boże ukrycie; doświadczenie religijne; dysonans doświadczeniowy; objawienie Boga. 